"The impact of quality management on inventories in commercial enterprises operating within group purchasing organizations"

\begin{tabular}{|c|c|}
\hline AUTHORS & $\begin{array}{l}\text { Grzegorz Zimon (D https://orcid.org/0000-0002-2040-4438 } \\
\text { R http://www.researcherid.com/rid/V-5509-2018 }\end{array}$ \\
\hline ARTICLE INFO & $\begin{array}{l}\text { Grzegorz Zimon (2019). The impact of quality management on inventories in } \\
\text { commercial enterprises operating within group purchasing organizations. } \\
\text { Problems and Perspectives in Management, 17(3), 362-369. } \\
\text { doi:10.21511/ppm.17(3).2019.29 }\end{array}$ \\
\hline DOI & http://dx.doi.org/10.21511/ppm.17(3).2019.29 \\
\hline RELEASED ON & Monday, 09 September 2019 \\
\hline RECEIVED ON & Tuesday, 02 July 2019 \\
\hline ACCEPTED ON & Tuesday, 20 August 2019 \\
\hline LICENSE & $\begin{array}{l}(\mathrm{cc}) \overline{\mathrm{EY}} \\
\text { This work is licensed under a Creative Commons Attribution } 4.0 \text { International } \\
\text { License }\end{array}$ \\
\hline JOURNAL & "Problems and Perspectives in Management" \\
\hline ISSN PRINT & $1727-7051$ \\
\hline ISSN ONLINE & $1810-5467$ \\
\hline PUBLISHER & LLC "Consulting Publishing Company "Business Perspectives" \\
\hline FOUNDER & LLC "Consulting Publishing Company "Business Perspectives" \\
\hline
\end{tabular}

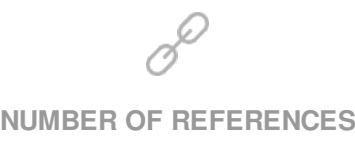

30
NUMBER OF FIGURES

1

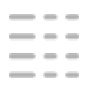

NUMBER OF TABLES

6

(C) The author(s) 2021. This publication is an open access article. 


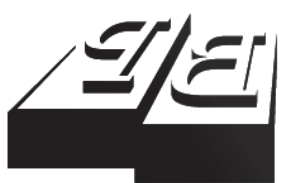

BUSINESS PERSPECTIVES

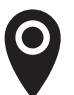

LLC "CPC "Business Perspectives" Hryhorii Skovoroda lane, 10, Sumy, 40022, Ukraine

www.businessperspectives.org

Received on: $2^{\text {nd }}$ of July, 2019 Accepted on: 20 th of August, 2019

(C) Grzegorz Zimon, 2019

Grzegorz Zimon, Ph.D., Department of Finance, Banking and Accounting, Rzeszow University of Technology, Poland.

\section{THE IMPACT OF QUALITY MANAGEMENT ON INVENTORIES IN COMMERCIAL ENTERPRISES OPERATING WITHIN GROUP PURCHASING ORGANIZATIONS}

\begin{abstract}
Inventory management costs are often high and it is necessary to introduce appropriate methods that cause their optimization. For this purpose, various types of methods supporting logistic processes are introduced. Joint activities within group purchasing organizations are also popular. Companies gain a possibility to reduce costs, in addition, when enterprises introduce appropriate quality management systems, the process of cost optimization and an improvement of inventory management efficiency should be even more visible. The purpose of this article is to analyze the impact of standardized quality management systems on inventory management. The research was conducted on a group of 68 enterprises operating in commercial group purchasing organizations. The enterprises were divided into two groups: into the companies using quality management systems and into those that do not use such systems. The analysis showed that the most frequently standardized quality management systems were used by large enterprises and the results of inventory management efficiency were at a similar level as compared to small units that do not apply quality management systems. The analysis based on selected financial indicators allows concluding that the introduction of quality management systems improves the efficiency of inventory management. The introduction of such systems allowed large enterprises to organize their warehouse management and reduce stocking reserves, which positively influenced the costs of managing them. The research period covers the years 2015-2017.
\end{abstract}

\section{Keywords}

quality, efficiency of inventory management, financial liquidity, group purchasing organization

\section{JEL Classification M21, P13, G30}

\section{INTRODUCTION}

Inventories in a company are designed to maintain the continuity of production and sales. The biggest problem when managing them is to set a level that is not too high or too low. This will be the optimal level thanks to which the costs of inventory management will be reduced accordingly. The problem with inventory management concerns not only the costs of maintaining their excessive level in warehouses, or the cost of lost opportunities resulting from the suspension of production. The problem that hardly anyone pays attention to is that keeping stocks too high means freezing cash into the least liquid current assets. Such inventory management policy may affect financial safety negatively. In an emergency, when the company saves liquidity and sells stocks, it loses a lot. Losses on sales in this situation can reach up to $40 \%$. Freezing cash in materials or goods that have not been used up or sold means expenses, not costs, and it is also important. Another problem concerns companies operating in group purchasing organizations, where purchases with large se- 
curity stocks often appear. They are aimed at increasing the scale effect of the whole group in order to obtain additional discounts. Orders over demand are costs. However, in purchasing groups there are opportunities to replenish inventories at favorable prices; the central warehouse of the purchasing group appears (Jovanovic et al., 2018).

Problems appearing in the inventory management process are a clear signal for the company management staff to introduce systems that improve the inventory management processes. In general, they introduce different types of systems that enable to plan the optimal size of the order, use JIT supplies, systematically control the level of inventory. However, even the best systems supporting work in the area related to inventory management will only fulfill their role if the employees fulfill their duties reliably. Very often, it can be noticed, especially in the area of inventory management, that the lack of an appropriate system of employee motivation, lack of control leads to negligence that costs the enterprise. They are not huge negligence or huge costs, but if they appear in several places in the supply chain, they can reduce the efficiency of inventory management. For this purpose, an introduction of appropriate quality management systems is a very good complement to logistics-related systems. These systems are very well suited to production-related enterprises. An employee responsible for a given production section needs to have the exact information where the products are manufactured, especially in the case of frequently occurring defects. Appropriately created quality management procedures allow one to thoroughly check and inspect such an employee. In small commercial enterprises, managers are generally reluctant to implement quality management systems. In general, in a well-organized unit, the management staff is able to maintain production and sales at a high level. However, there are groups of enterprises which, as a result of emerging needs, or because of the prevailing fashion for ISO, introduce quality management systems. The purpose of the paper is to analyze and evaluate how companies having standardized quality management systems manage stocks efficiently. The survey was conducted on a group of 68 entities operating in commercial group purchasing organizations (GPOs).

\section{LITERATURE REVIEW}

Inventory management is very important for companies from the point of view of financial liquidity. Very often, in the area related to inventories, there is an assortment with low turnover in days, which over time increasingly affects the real financial liquidity of the company. The inventory management process is not just logistics. Marketing is becoming more and more important, as it places a strong emphasis on the decision-making process in the enterprise (Tang, 2010). It also concerns areas related to inventories, the role of promotions and discounts for increasing the purchases offered by producers is every day. Its impact is of great importance for the finances of the company and for shopping with large reserves (Arya \& Mittendorf, 2013; Moon et al., 2017; Marand et al., 2018). Creating reserves is the cost of inventory management, so it is necessary to analyze whether it is profitable for the company at a given moment. Inventory management is based on determining the appropriate levels in the warehouse, which ensure continuity of sales without unnecessary downtimes or in the case of production units and production continuity. In the literature on inventory management, one can find a number of studies on the appropriate location of warehouses and their design (Sainathuni et al., 2014). Many methods and tools have been developed to streamline the warehouse management process (G. Zimon \& D. Zimon, 2019a; Heragu et al., 2005; Ng et al., 2009, Parikh \& Meller, 2010). The area of particular interest in the storage process is the preservation of order, which improves the efficiency of inventory management (Tompkins et al., 2010). In recent years, distribution planning scholars have devoted considerable attention to integration (Li \& Wang, 2018).

In the literature one can find studies where the authors point to the need to optimize the level of costs related to inventory management, e.g. costs related to the organization of orders and deliveries, purchase costs, payroll costs, external services costs, orders, inaccuracies in the inventory process, supply chain improvements (Kok \& Shang, 2007; Rekik, 2011; DeHoratius et al., 2008; Sahin \& Dallery, 2009; Shvartsburg et al., 2017). 


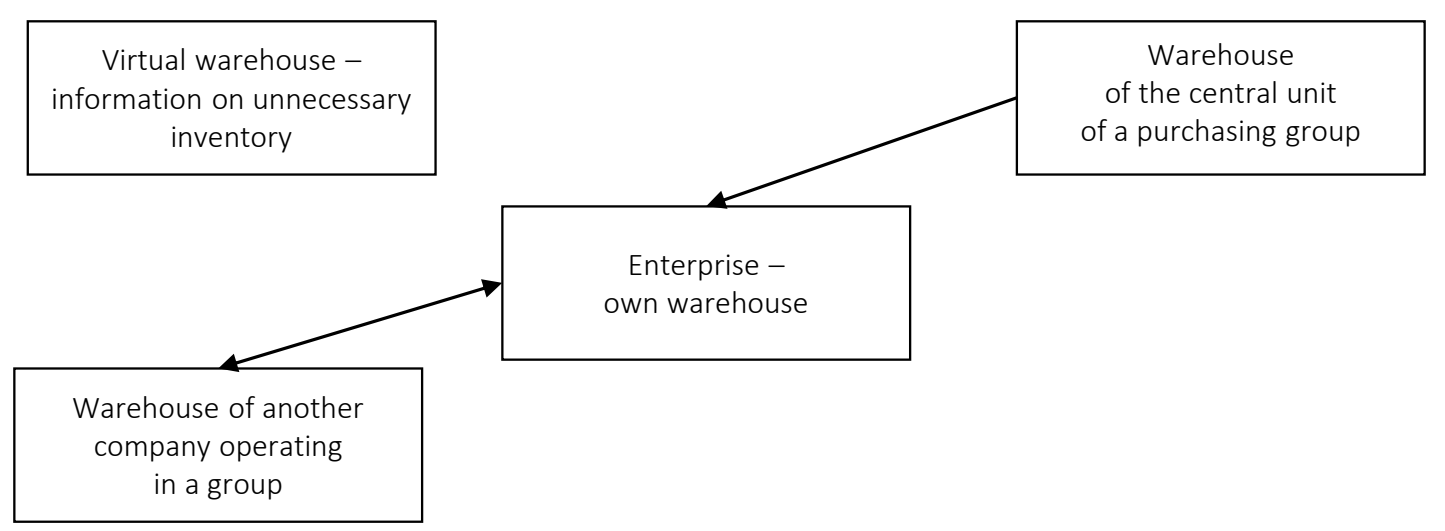

Figure 1. Functioning of warehouses in a commercial group purchasing organization

In order to optimize inventory management costs, enterprises try to use public external warehouses. Thanks to this enterprise can reduce the costs of capital investments on storage facilities, the costs of renting and maintaining the warehouse, thus avoiding the costs of unnecessary space (Rosales et al., 2013; Van der Heide et al., 2018; Murphy \& Wood, 2004). An introduction of this type of warehouses is intended to help in minimizing inventory levels and establishing economic order quantity - EOQ (Cormier \& Gunn, 1996). Warehouses of central purchasing group units operate in a similar way to external warehouses.

The central warehouse in purchasing groups works very well and the central unit of the group sells goods and materials to the participants of the group. When analyzing stock management of purchasing groups, it can be stated that companies operating in groups can use three warehouses. The details of the functioning of warehouses in purchasing groups are presented in Figure 1.

Companies operating in a group purchasing organization use the same financial and accounting programs and within these programs an appropriate folder was created. It contains information on unnecessary inventories created for individual enterprises. This folder can be described as a "virtual warehouse". In the purchasing groups, mutual transactions also appear, whose purpose is to help enterprises with financial risk. In a sense, this can be defined as an ability to use the friendly company's warehouse within the group.

High inventories often mean a reduction in the efficiency of their management. Inventory management and maintaining a high level of inventory is a necessity to increase employment. However, often managers do not do so, but they exploit the employees.

There are authors who believe that excessive overloading of warehouse employees affects negatively the efficiency of warehouse management and creates unjustified costs (Parikh \& Meller, 2009). In general, when the company managers are looking for savings, the process of cost reductions starts with managing wages, reduction of employment or maintaining wages at the same levels. In fact, such an action reduces the efficiency of work of warehouse employees. Remuneration management strategies would make sense if it started with the reduction of management board salaries, but such situations are generally not found in small, large, private and, above all, state-owned enterprises.

An introduction of a strategy to cut the costs of inventory management will not bring beneficial results in the long run. In crisis situations, one can reduce the company operating costs by lowering warehouse management costs. However, it is worth finding solutions that will increase the efficiency of inventory management. Most often, appropriate logistics management systems are introduced, e.g. EOQ, JIT, various types of inventory classification methods. This is the first basic step that needs to be made to improve the efficiency of inventory management. The second step should be an introduction of appropriate quality management systems. Lack of appropriate employee motivation systems on the line of warehousemen transport is a major source of negligence in the inventory management process. Human factor and errors, omissions, lack of incentive to work more 
effectively result in unnecessary costs of inventory management. In order not to admit such situations, an appropriate employee motivation system, their control and most importantly appropriate quality management systems should be introduced.

The introduction of standardized quality management systems improves the process of controlling warehouse employees, reduces warehouse management costs, which positively affects the process of inventory management (Fonseca \& Domingues, 2017; Zaramdini, 2007; Sampaio et al., 2012; Dellana \& Kros, 2018). The customer usually buys the goods, the service pays attention to the price, the trade credit, and next to time and the quality of service. The introduction of quality management systems is designed to improve this third element but also has a large impact on costs. A decrease in costs may cause a reduction in the price of products sold, i.e. quality management systems have a direct impact on the price, which is the most important criterion that the buyer of the good or service is guided by.

\section{METHODOLOGY}

The research covered Polish enterprises belonging to commercial purchasing groups operating in the construction industry.

The analysis included 68 Polish commercial enterprises operating in five purchasing groups, which account for $75 \%$ of all enterprises. The research period concerned the years 2015-2017. The analysis was carried out to assess the impact of standardized quality management systems on the inventory management process. In the literature, one can find different opinions on the need to apply quality management systems in commercial enterprises, but at- tempts to assess their impact on the management of individual assets appear very rarely (D. Zimon \& G. Zimon, 2019b; Wyrwa \& Ziólkowski, 2016).

The enterprises surveyed were divided into those that implemented quality management systems (28 enterprises) and those that did not use such solutions (40 enterprises). Next, analyzes and comparisons of results obtained by enterprises associated in particular groups were made. The selected financial indicators and basic statistical methods were used as the basic research tools.

\section{EMPIRICAL RESULTS AND DISCUSSION}

The first element analyzed was the share of inventories in current assets. It is an important measure because it indicates to what extent the least liquid current assets constitute a share in total current assets. The lower the result of this ratio is achieved by enterprises, the higher their financial safety. It is better if the share of receivables from recipients is higher than inventories in the structure of current assets.

In the companies analyzed, inventories are clearly higher. This is due to joint purchases. Enterprises operating in the group purchasing organizations try to take advantage of economies of scale and order a given product with a large security reserve. Differences in the average level of participation between enterprises applying quality management systems and those that do not use such systems were statistically significant in 2015 and 2017. The ratio of inventories in current assets in enterprises applying standardized quality management systems is - on average - approx. 0.10 higher compared to units not using quality management systems. The details are presented in Table 1.

Table 1. Average results for the inventory share ratio in the analyzed enterprises

Source: Author's own research.

\begin{tabular}{|c|c|c|c|c|c|c|c|c|c|c|c|}
\hline \multirow{2}{*}{$\begin{array}{l}\text { Inventory } \\
\text { share ratio }\end{array}$} & \multicolumn{5}{|c|}{$\begin{array}{c}\text { Companies that do not use quality } \\
\text { management systems }(N=40)\end{array}$} & \multicolumn{5}{|c|}{$\begin{array}{l}\text { Companies that use quality management } \\
\text { systems }(N=28)\end{array}$} & \multirow{2}{*}{$p$} \\
\hline & $\bar{x}$ & Me & $S$ & $\min$ & $\max$ & $\bar{x}$ & Me & $s$ & $\min$ & $\max$ & \\
\hline 2015 & 0.47 & 0.50 & 0.14 & 0.21 & 0.74 & 0.55 & 0.57 & 0.07 & 0.33 & 0.66 & $0.0081^{* *}$ \\
\hline 2016 & 0.53 & 0.54 & 0.12 & 0.13 & 0.70 & 0.62 & 0.64 & 0.11 & 0.31 & 0.70 & $0.0086^{* *}$ \\
\hline 2017 & 0.54 & 0.56 & 0.16 & 0.11 & 0.72 & 0.60 & 0.63 & 0.09 & 0.28 & 0.75 & $0.0258^{*}$ \\
\hline
\end{tabular}

Note: * statistically significant relationship; ** highly relevant dependencies 
Table 2. Average results for the inventory turnover ratio in days in the analyzed enterprises

Source: Author's own research.

\begin{tabular}{|c|c|c|c|c|c|c|c|c|c|c|c|}
\hline \multirow{2}{*}{$\begin{array}{c}\text { Inventory } \\
\text { turnover ratio } \\
\text { in days }\end{array}$} & \multicolumn{5}{|c|}{$\begin{array}{l}\text { Companies that do not use quality } \\
\text { management systems }(N=40)\end{array}$} & \multicolumn{5}{|c|}{$\begin{array}{l}\text { Companies that use quality management } \\
\text { systems }(N=28)\end{array}$} & \multirow{2}{*}{$p$} \\
\hline & $\bar{x}$ & Me & $s$ & $\min$ & $\max$ & $\bar{x}$ & Me & $s$ & $\min$ & $\max$ & \\
\hline 2015 & 68.4 & 62.0 & 18.7 & 42.3 & 122.4 & 68.6 & 69.0 & 15.8 & 47.1 & 103.1 & 0.5856 \\
\hline 2016 & 69.0 & 60.5 & 17.8 & 41.7 & 119.2 & 70.2 & 70.0 & 20.2 & 41.6 & 128.7 & 0.3940 \\
\hline 2017 & 71.7 & 68.5 & 18.9 & 44.6 & 133.1 & 72.4 & 68.2 & 22.0 & 40.5 & 124.8 & 0.5760 \\
\hline
\end{tabular}

The comparison of inventory turnover ratios in days is very important for inventory management assessment. The detailed result is presented in Table 2.

A slightly longer deadline for rotation occurs in enterprises applying quality management systems. It could be said that quality management systems do not fulfill their role. In order to complete the assessment, it is worth giving the average value of inventories in the analyzed groups in particular years. The details are presented in Table 3 .

Table 3. Average results of inventory in the analyzed enterprises

\begin{tabular}{c|c|c} 
& Source: Author's own research. \\
\hline $\begin{array}{c}\text { Inventory } \\
\text { size }\end{array}$ & $\begin{array}{c}\text { Companies } \\
\text { that use quality } \\
\text { management } \\
\text { systems }(\boldsymbol{N}=\mathbf{2 8})\end{array}$ & $\begin{array}{c}\text { Companies } \\
\text { that do not use } \\
\text { quality management } \\
\text { systems }(\boldsymbol{N}=\mathbf{4 0})\end{array}$ \\
\hline 2015 & $\bar{x}$ & $\bar{x}$ \\
\hline 2016 & $17.6 \mathrm{mln}$ PLN & $3.2 \mathrm{mln}$ PLN \\
\hline 2017 & $21.3 \mathrm{mln}$ PLN & $5.1 \mathrm{mln}$ PLN \\
\hline
\end{tabular}

Enterprises using standardized quality management systems are generally large enterprises. Despite several times higher inventory levels than those which do not use quality management systems, inventory rotation ratios achieve similar results. In turn, the largest enterprises from the group of entities that do not use quality man- agement systems characterized by high inventory levels, obtain weaker results on the inventory turnover by an average of about 8 days. It can be seen that the quality management systems make it easier to manage inventory. The high level of inventories is confirmed by the results of financial liquidity ratios, especially the quick liquidity ratio. Detailed results for the financial liquidity ratio are presented in Table 4.

In the units analyzed, the median results for enterprises using standardized quality management systems are clearly higher than those that do not use such systems. If the financial liquidity analysis is carried out with the use of fast liquidity ratio, i.e. without the use of inventories in current assets, the results in both groups are similar. Details are presented in Table 5.

The next stage of the analysis was to examine the correlation between financial ratios determining the Spearman rank correlation coefficient matrix between pairs of ratios. Table 6 presents the values of correlation coefficients, statistically significant by the symbol *.

Inventories turnover ratio is quite strongly related to the ratio of inventory, financial liquidity, quick financial liquidity and share of inventories in current assets. This connection clearly suggests that it is worth introducing new method tools that improve stock rotation in days, which will have a

Table 4. Average results for the financial liquidity ratio in the analyzed enterprises

Source: Author's own research.

\begin{tabular}{|c|c|c|c|c|c|c|c|c|c|c|c|}
\hline \multirow{2}{*}{$\begin{array}{c}\text { Financial } \\
\text { liquidity ratio }\end{array}$} & \multicolumn{5}{|c|}{$\begin{array}{c}\text { Companies that do not use quality } \\
\text { management systems }(N=40)\end{array}$} & \multicolumn{5}{|c|}{$\begin{array}{c}\text { Companies that use quality management } \\
\text { systems }(N=28)\end{array}$} & \multirow{2}{*}{$p$} \\
\hline & $\bar{x}$ & Me & $s$ & $\min$ & $\max$ & $\bar{x}$ & Me & $s$ & $\min$ & $\max$ & \\
\hline 2015 & 3.88 & 1.80 & 3.21 & 0.18 & 11.0 & 2.60 & 2.70 & 0.88 & 1.34 & 6.2 & 0.5007 \\
\hline 2016 & 4.01 & 1.70 & 3.29 & 1.20 & 13.0 & 3.16 & 3.24 & 0.78 & 1.26 & 8.2 & 0.4820 \\
\hline 2017 & 3.90 & 1.95 & 2.89 & 1.22 & 11.0 & 2.92 & 2.30 & 1.65 & 1.22 & 9.0 & 0.5621 \\
\hline
\end{tabular}


Table 5. Average results for the quick ratio in the enterprises analyzed

Source: Author's own research.

\begin{tabular}{|c|c|c|c|c|c|c|c|c|c|c|c|}
\hline \multirow{2}{*}{$\begin{array}{l}\text { Quick } \\
\text { ratio }\end{array}$} & \multicolumn{5}{|c|}{$\begin{array}{l}\text { Companies that do not use quality } \\
\text { management systems }(N=40)\end{array}$} & \multicolumn{5}{|c|}{$\begin{array}{l}\text { Companies that use quality management } \\
\text { systems }(N=28)\end{array}$} & \multirow{2}{*}{$p$} \\
\hline & $\bar{x}$ & Me & $s$ & $\min$ & $\max$ & $\bar{x}$ & Me & $s$ & $\min$ & $\max$ & \\
\hline 2015 & 1.90 & 0.95 & 1.78 & 0.28 & 7.10 & 1.21 & 1.05 & 0.50 & 0.15 & 1.80 & 0.6921 \\
\hline 2016 & 1.78 & 1.00 & 1.76 & 0.34 & 6.20 & 1.44 & 1.47 & 0.56 & 0.30 & 2.10 & 0.8748 \\
\hline 2017 & 1.81 & 0.98 & 1.53 & 0.26 & 4.00 & 1.30 & 1.22 & 0.51 & 0.40 & 2.10 & 0.6722 \\
\hline
\end{tabular}

Table 6. Values of correlation coefficients for selected ratios

Source: Author's own research.

\begin{tabular}{c|c|c|c|c}
\hline Financial ratios 2017 & Share & Liquidity & Inventories turnover ratio & Quick ratio \\
\hline Inventories turnover ratio & $-0.64^{*}$ & $0.66^{*}$ & 1 & 0.19 \\
\hline
\end{tabular}

positive impact on the abovementioned indicators, which are related to financial security and inventory management costs.

The introduction of standardized quality management systems was evaluated positively by the management team as it allowed locating warehouse deposits, leading to their liquidation and by introducing appropriate procedures allowed the management team to improve the process of warehouse employees' work control. These activities enabled to lower the level of losses in the warehouse, which reduced the level of inventory management costs. However, these costs constitute a small share in the structure of the total costs of operations of large enterprises.

\section{CONCLUSION}

The analysis conducted did not show clearly that in enterprises using standardized quality management systems in the area of inventory management, better management efficiency was noted. The results of inventory turnover in days in both groups of enterprises are at a similar level. However, when analyzing in detail the size of inventories, it was observed that enterprises that generate the highest turnover and have large amounts of inventory, they, above all, use quality management systems. Their results regarding the efficiency of inventory management are at a similar level to small enterprises that do not have quality management systems. Large enterprises, in spite of high inventory levels in the structure of current assets, do not have worse results of inventory turnover ratios. This shows the need to use the tools offered by quality management systems that will improve the work related to inventory management in the warehouse. With large inventories, warehouse deposits are often created, which reduces the efficiency of inventory management. Through an introduction of quality management systems, the work of warehouse employees and the share of individual assortments in the structure of inventory have been ordered. During the process of introducing quality management systems, the level of storage deposits was reduced.

Confirmation of high stock levels in the enterprises analyzed is reflected in the results of liquidity ratios and quick financial liquidity. Higher results are obtained by enterprises using quality management systems. However, it is worth running a stock management policy to lower the share of inventories in current assets, for receivables or cash. This will positively affect the company financial security. By introducing standardized quality management systems in every enterprise, there must be an improvement in inventory management, a decrease in inventory turnover in days. There are certain inventory management systems for which it is necessary to have appropriate quality management systems, e.g. a JIT system where the appearance of deliveries of low-quality goods or materials means practically stopping the company's operations. 
In addition, the large quality management has a strong impact on employees, the introduction of appropriate procedures in the area of warehouse management, delivery, transport allows finding those responsible for errors arising throughout the supply chain. The reduction of faults and mistakes by employees is the first step to improve the efficiency of inventory management. However, the biggest barrier preventing the introduction of quality management systems is the management of the company and the reluctance of the management to introduce standardized quality management systems. Such a view of the board is mostly influenced by three elements: the costs of introducing systems, the reluctance of employees to change and new obligations, increasing documentation and the lack of financial effects visible to the owners to the introduction of quality management systems. However, in the long run, the introduction of quality management systems seems to be a necessity. The fight for winning a new contractor or maintaining a permanent one is becoming more and more difficult and in order to be competitive one needs to function efficiently and effectively. Standardized quality management systems are just such a tool that can increase the efficiency of business management, e.g. in the area of inventory, which should translate into gaining an advantage over a competitor in the fight for new contractors.

\section{REFERENCES}

1. Arya, A., \& Mittendorf, B. (2013). Managing strategic inventories via manufacturer-to-consumer rebates. Management Science, 59(4), 813-818. https://doi.org/10.1287/ mnsc. 1120.1626

2. Cormier, G., \& Gunn, E. A. (1996). On coordinating warehouse sizing, leasing and inventory policy. IIE Transactions, 28(2), 149-154. https://doi. org/10.1080/07408179608966260

3. DeHoratius, N., Mersereau, A. J., \& Schrage, L. (2008). Retail inventory management when records are inaccurate. Manufacturing \& Service Operations Management, 10(2), 257-277. Retrieved from https://pubsonline.informs.org/ doi/10.1287/msom.1070.0203

4. Dellana, S., \& Kros, J. (2018). ISO 9001 and supply chain quality in the USA. International Journal of Productivity and Performance Management, 67(2), 297-317. https://doi.org/10.1108/ IJPPM-05-2015-0080

5. Fonseca, L., \& Domingues, J. P. (2017). ISO 9001: 2015 editionmanagement, quality and value. International Journal of Quality Research, 11(1), 149-158. Retrieved from http://www.ijqr.net/ journal/v11-n1/9.pdf

6. Heragu, S. S., Du, L., Mantel, R. J., \& Schuur, P. C. (2005). Mathematical model for warehouse design and product allocation.
International Journal of Production Research, 43(2), 327-338. https:// doi.org/10.1080/0020754041233 1285841

7. Jovanović, I., Arsić, M., \& Nikolić, D. (2018). Entrepreneurial personality traits and SMEs profitability in transition economy. Serbian Journal of Management, 13(1), 89-104. Retrieved from https://www.researchgate.net/ publication/324616697_Entrepreneurial_personality_traits_and_ SMEs_profitability_in_transition_economy

8. Kök, A. G., \& Shang, K. H. (2007). Inspection and replenishment policies for systems with inventory record inaccuracy. Manufacturing \& Service Operations Management, 9(2), 185-205. Retrieved from https://pdfs.semanticscholar.org/8fb5/e544d81876c80cb5c54cce471d5da198ac50.pdf

9. Li, M., \& Wang, Z. (2017). An integrated replenishment and production control policy under inventory inaccuracy and timedelay. Computers and Operations Research, 88, 137-149. Retrieved from https://dl.acm.org/citation. cfm?id=3138901

10. Marand, A. J., Li, H., \& Thorstenson, A. (2018). Joint inventory control and pricing in a serviceinventory system. International Journal of Production Economics, 209, 78-91. https://doi. org/10.1016/j.ijpe.2017.07.008
11. Ming, L., \& Zheng, W. (2017). An integrated replenishment and production control policy under inventory inaccuracy and timedelay. Computers and Operations Research, 88, 137-149. https://doi. org/10.1016/j.cor.2017.06.014

12. Moon, I., Dey, K., \& Saha, S. (2018). Strategic inventory: Manufacturer vs. retailer investment. Transportation Research Part E: Logistics and Transportation Review, 109, 63-82. https://doi. org/10.1016/j.tre.2017.10.005

13. Murphy, P. R., \& Wood, D. F. (2004). Contemporary logistics (8th ed.). Now York: Pearson Education.

14. Ng, C., Cheng, T., Kotov, V., \& Kovalyov, M. Y. (2009). The EOQ problem with decidable warehouse capacity: Analysis, solution approaches and applications. Discrete Applied Mathematics, 157(8), 1806-1824. https://doi. org/10.1016/j.dam.2009.01.004

15. Parikh, P. J., \& Meller, R. D. (2009). Estimating picker blocking in wide-aisle order picking systems. IIE Transactions, 41(3), 232-246. https://doi. org/10.1080/07408170802108518

16. Parikh, P. J., \& Meller, R. D. (2010). A note on worker blocking in narrow-aisle order picking systems when pick time is non-deterministic. IIE Transactions, 42(6), 392-404. https://doi. org/10.1080/07408170903171043 
17. Rekik, Y. (2011). Inventory inaccuracies in the wholesale supply chain. International Journal of Production Economics, 133(1), 172-181. https://doi.org/10.1016/j. ijpe.2010.02.012

18. Rosales, C., Rao, U., \& Rogers, D. (2013). Retailer transshipment versus central depot allocation for supply network design. Decision Sciences, 44(2), 329-356. https:// doi.org/10.1111/deci.12011

19. Sahin, E., \& Dallery, Y. (2009). Assessing the impact of inventory inaccuracies within a newsvendor framework. European Journal of Operational Research, 197(3), 1108-1118. https://doi. org/10.1016/j.ejor.2008.03.042

20. Sainathuni, B., Parikh, P. J., Zhang, X., \& Kong, N. (2014). The warehouse-inventory-transportation problem for supply chains. European Journal of Operational Research, 237(2), 690-700. https:// doi.org/10.1016/j.ejor.2014.02.007

21. Sampaio, P., Saraiva, P., \& Domingues, P. (2012). Management systems: integration or addition? International Journal of Quality \& Reliability Management, 29(4), 402-424. https://doi org/10.1108/02656711211224857

22. Shvartsburg, L., Zaborowski, T., \& Cyplik, P. (2017). Situation of costs in the logistic process of enterprises. Logforum, 13(4), 495-506. Retrieved from http:// yadda.icm.edu.pl/yadda/element/ bwmeta1.element.ekon-element-000171480335

23. Tang, C. S. (2010). A review of marketing-operations interface models: from co-existence to coordination and collaboration. International Journal of Production Economics, 125(1), 22-40. http://dx.doi.org/10.1016/j. ijpe.2010.01.014

24. Tompkins, J. A., White, J. A., Bozer, Y. A., \& Tanchoco, J. M. A (2010). Facilities planning. NY: John Wiley and Sons.

25. Wyrwa, D., \& Ziółkowski, B. (2015). Quality management systems in competitive strategies of polish enterprises. In Production Management and Engineering Sciences - Scientific Publication of the International Conference on Engineering Science and Production Management, ESPM 2015 (pp.327-332)

26. Van der Heide, G., Van Foreest, N. D., \& Roodbergen, K. J. (2018). Optimizing stock levels for rental systems with a support warehouse and partial backordering. European Journal of Operational Research, 265(1), 107-118. https:// doi.org/10.1016/j.ejor.2017.07.040

27. Zaramdini, W. (2007). An empirical study of the motives and benefits of ISO 9000 certification: the UAE experience. International Journal of Quality \& Reliability Manage- ment, 24(5), 472-491. https://doi. org/10.1108/02656710710748358

28. Zimon, D. (2015). Impact of the implementation of quality management system on operating cost for small and medium-sized business organizations affiliated to a purchasing group. International Journal for Quality Research, 9(4) 551-564. Retrieved from https:// web.a.ebscohost.com/abstract?site $=$ ehost $\&$ scope $=$ site \&jrnl $=18006$ 450\&AN $=111599632 \& \mathrm{~h}=\mathrm{lX} \% 2 \mathrm{fv}$ ObGfrskYfZZApQOjE\%2bTHAjA vKcywPGD3RiFAMW8ZK3tQJQ A37y1KB3KjlaVXsmDJcVULlqKb FMavARNtVQ\%3d\%3d\&crl=c\&re sultLocal=ErrCrlNoResults\&resul $\mathrm{tNs}=$ Ehost $\&$ crlhashurl=login.aspx $\% 3$ fdirect $\% 3$ dtrue $\% 26$ profile $\% 3 \mathrm{de}$ host $\% 26$ scope $\% 3$ dsite\%26authtyp e\%3dcrawler\%26jrnl\%3d18006450 \%26AN\%3d111599632

29. Zimon, G., \& Zimon, D. (2019a). An Assessment of the Influence of Nominalized Quality Management Systems on the Level of Receivables in Enterprises Operating in Branch Group Purchasing Organizations. QUALITY-ACCESS TO SUCCESS, 20(169), 47-51.

30. Zimon, D., \& Zimon, G. (2019b). The Impact of Implementation of Standardized Quality Management Systems on Management of Liabilities in Group Purchasing Organizations. Quality Innovation Prosperity, 23(1), 60-73. http://dx.doi.org/10.12776/qip. v23i1.1210 